NBER WORKING PAPER SERIES

UNDISCLOSED DEBT SUSTAINABILITY

Laura Alfaro

Fabio Kanczuk

Working Paper 26347

http://www.nber.org/papers/w26347

\author{
NATIONAL BUREAU OF ECONOMIC RESEARCH \\ 1050 Massachusetts Avenue \\ Cambridge, MA 02138 \\ October 2019
}

The paper does not reflect the views of the World Bank Group, the World Bank Board or any of the Governments represented by Fabio Kanczuk. Support from Harvard Business School research budget acknowledged. The views expressed herein are those of the authors and do not necessarily reflect the views of the National Bureau of Economic Research.

NBER working papers are circulated for discussion and comment purposes. They have not been peer-reviewed or been subject to the review by the NBER Board of Directors that accompanies official NBER publications.

(C) 2019 by Laura Alfaro and Fabio Kanczuk. All rights reserved. Short sections of text, not to exceed two paragraphs, may be quoted without explicit permission provided that full credit, including (C) notice, is given to the source. 
Undisclosed Debt Sustainability

Laura Alfaro and Fabio Kanczuk

NBER Working Paper No. 26347

October 2019

JEL No. F0,F34

\begin{abstract}
Over the past decade, non-Paris Club creditors, notably China, have become an important source of financing for low- and middle-income countries. In contrast with typical sovereign debt, these lending arrangements are not public, and other creditors have no information about their magnitude. We transform the traditional sovereign debt and default model to quantitatively study incomplete information arrangements and find they greatly reduce traditional/Paris Club creditors' debt sustainability. Disclosure of nontraditional debt would imply significant welfare gains for the recipient countries but would reduce its sustainability. We discuss the implications of nontraditional lending on standard assumptions of sovereign debt models in particular defaulting costs.
\end{abstract}

\title{
Laura Alfaro
}

Harvard Business School

Morgan Hall 263

Soldiers Field

Boston, MA 02163

and NBER

lalfaro@hbs.edu

Fabio Kanczuk

University of São Paulo

R. Dr Alberto Cardoso de Melo Neto 110/131A

Sao Paulo-S.P.-CEP 01455-100

BRAZIL

kanczuk@usp.br 


\section{Introduction}

China's development has reshaped the world economy. In the last two decades, strong domestic growth and the related demand for natural resources led China to search for markets abroad. Countries in Africa, East Asia, and Latin America were natural partners, with an abundance of commodities and need for infrastructure development. In addition to redefining world trade patterns, China's venturing abroad has reshaped international lending. Low- and middle-income countries have increased their reliance on financing from nontraditional sources (Figure 1). It has been suggested, for example, that over the last decade China has financed more than 3,500 projects in Africa, worth almost $\$ 300$ billion in official financing. As a result, China has become the region's largest creditor, accounting for $15 \%$ of sub-Saharan Africa's total debt stock (AidData Project and Foresight Africa, 2018).

China, as a non-member of the Paris Club, does not report on its official lending and, there is no comprehensive data on Chinese overseas financing (Horn, Reinhart, Trebesch, 2010). ${ }^{1}$ In recent years, China's increased presence in international financial markets, and the lack of information of the actual extent of its investments, has attracted the attention of multilateral institutions and international investors. According to the World Bank (International Debt Statistics, 2018), non-Paris Club (NPC) debt accounted for about 13\% of low-income countries' public debt in 2016 (World Bank, 2018b). Given the lack of official data, these are estimates compiled from different sources.

This paper studies how undisclosed debt affects debt sustainability. We transform the now traditional sovereign debt and default model to include incomplete information arrangements. In addition to the usual traditional "international investors" (Paris Club) credit

\footnotetext{
${ }^{1}$ China is not a member of the Paris Club and does not follow its disclosure requirements. Horn, Reinhart, Trebesch (2010) estimate that almost all of China's overseas lending is official and close to half of China's lending to developing countries is "hidden" and not recorded in the main databases.
} 
market, the sovereign may borrow an undisclosed amount of debt from an NPC investor. International investors thus have to assess NPC debt to adequately charge for their lending.

The lack of consistent statistics highlights a critical issue across NPC borrowing and lending: limited transparency. Unlike usual sovereign debt, lending arrangements by non-Paris Club creditors are not public. As such, they increase funding costs from the original international creditors, who reassess the probability of being repaid. Increased exposure to NPC members and commercial creditors may pose coordination challenges for debt resolution, making the consequences of debt distress even more disruptive.

The IMF and the World Bank have recently highlighted debt transparency as a critical issue in the current G20 agenda. At a 2018 IMF meeting, Christine Lagarde urged borrowers and their new creditors to be more transparent about their liabilities. "Borrowing from nonParis Club lenders also means that creditor coordination will likely become more complicated...A key challenge is preventing 'debt surprises,' which can be driven by poor governance, off-balance sheet borrowing, and weak debt recording and reporting" (Reuters, September 13, 2018). Horn, Reinhart, Trebesch (2010) summarize the state of affairs by stating that "these hidden overseas debts pose serious challenges for country risk analysis and bond pricing. Debt sustainability metrics are poorer than generally perceived, especially so in about two dozen developing countries that borrowed heavily from China during the boom decade of 2003-2013. Moreover, private investors may not appreciate the extent to which they are junior to the Chinese government."

In this paper, we model an economy populated by a continuum of private households, a benevolent government, a continuum of risk-neutral international investors, and an NPC investor that is also assumed to be risk-neutral. Preferences are concave, implying that households prefer a smooth consumption profile. The novelty of our model is that the international investors have no information regarding the amount of a government's debt to the 
NPC investor, thus mirroring scenarios with opaque information. Lending from nontraditional sources also requires rethinking the costs associated with defaulting including potential exclusions from different capital markets. In the benchmark case, we assume a government that defaults on its debts to be temporarily excluded from borrowing in the market in which it defaulted.

We choose to calibrate our model to the Angolan economy. With an estimated debt of over US\$25 billion, Angola is one of the African countries most indebted to China. In the robustness check section, we analyze additional countries with different perceived exposures to Chinese borrowing and lending.

We solve three scenarios with our model: (i) a case without the NPC investor (to reflect the environment before China's recent economic growth and its Belt and Road strategy); (ii) the current equilibrium, with the presence of the NPC investor and incomplete information about its debt; (iii) a hypothetical case where there is disclosure of NPC debt and information is transparent. When compared to the original environment (version i), NPC undisclosed lending (version ii) results in a reduction in the original investor's debt sustainability. We quantitatively study this effect and determine that greater original debt results in more severe decreases in debt sustainability; defaults and market exclusion episodes happen more often, but there is a substantial increase in the recipient country's welfare. We also find that version (iii) - the hypothetical case with complete information - results in even higher welfare gains for the recipient country. However, this equilibrium results in significant reduction in the NPC debt sustainability.

In the robustness check section, we analyze alternative scenarios in terms of defaulting costs. In particular, we present a case in which China's lending is a substitute rather than a 
complement to the other countries, with different implications for output costs. We also analyzed the role of collateralized lending. ${ }^{2}$

Our paper contributes to the growing literature that examines debt sustainability (see Aguiar and Amador (2014) and Aguiar et al. (2016) for recent surveys of the literature). An important implication of our analysis relates to the cost traditionally associated with debt default. Some of our results depend crucially on different assumptions that have been at the core of the traditional sovereign debt models, such as defaulting costs and exclusion (Eaton and Gersovitz, 1981; Bulow and Rogoff, 1989; Cole and Kehoe, 1995; Alfaro and Kanczuk, 2005, 2009; Arellano, 2008; Mendoza and Yue, 2012). These assumptions matter for debt sustainability. As countries increasingly transition to borrowing and lending to non-traditional markets and non-atomistic players such as China, consequences of defaulting may unravel differently from previous episode.

This paper also complements previous research that has studied the role of sovereignto-sovereign capital flows and lending (Alfaro and Kanczuk, 2009; and Alfaro et al., 2014). In addition, it aims to understand the role of China's capital exports in the world economy. Recent work has begun to document China's role in world financial markets (Horn et al., 2019; Agarwal, Gu, and Prasad, 2019) and monetary systems (Farhi and Maggiori, 2019; Ilzetzki, Reinhart and Rogoff, 2019.

Section 2 describes the model and the equilibrium concept. Section 3 reports the parameter calibration. Section 4 shows the simulation results and links them to current discussions. Section 5 presents robustness checks that evaluate the sensitivity of results to parameters and analyzes the case of collateralized NPC debt. Section 6 concludes.

\footnotetext{
${ }^{2}$ Collateralized debt has become common in various lending arrangements (e.g. case of Sri Lanka).
} 


\section{Model}

We model an economy populated by a continuum of private households, a benevolent government, a continuum of risk-neutral international investors, and a non-Paris Club investor that is also assumed to be risk-neutral. The continuum of risk-neutral investors is meant to represent the international credit market, which is composed of private investors, governments, and multilateral banks. Although heterogenous and not fully competitive, this market is estimated to have a constant (marginal) lending rate and must disclose the amount loaned. We similarly model the NPC investor by setting a lending rate meant to represent its opportunity cost. However, in contrast with the "international investors," the NPC investor does not release information about the amount loaned.

Preferences are concave, implying that households prefer a smooth consumption profile. To smooth consumption, the benevolent government may choose optimally to default on its commitments. A government that defaults on its debts is assumed to be temporarily excluded from borrowing in the market in which it defaulted. That is, if the government defaults on debt to international investors, it is temporarily excluded from borrowing from them but can still borrow from the NPC investor. Similarly, if the government defaults on the debt to NPC investor, it can still borrow from international investors. As mentioned, the novelty of our model is that the international investors do not have information on the amount of NPC debt.

We assume the sovereign's preferences to be given by:

$$
U=E \sum_{t=0}^{\infty} \beta^{t} u\left(c_{t}\right)
$$

with:

$$
u(c)=\frac{c^{(1-\sigma)}}{(1-\sigma)}
$$

where $E$ is the expectation operator $c_{t}$ denotes households' consumption, $\sigma>0$ measures the 
curvature of the utility, and $\beta \in(0,1)$ is the discount factor. Households receive a stochastic stream of a tradeable good $y_{t}$, which is a Markov process with transition function $f\left(y_{t^{+}}, y_{t}\right)$.

If the government chooses to repay its debt to both international and NPC investors, the country's budget constraint is given by:

$$
c_{t}+q_{t}^{B} B_{t+1}+q_{t}^{D} D_{t+1}=y_{t}+B_{t}+D_{t}
$$

where $B_{t}$ denotes the debt owed to international investors, $D_{t}$ the debt owed to the NPC, and $y_{t}$ the output endowment. The debt price schedules $q^{B}$ and $q^{D}$ are endogenously determined and are dependent on the state of the economy, $s_{t}$, as well as on the government's decisions. The state of the economy is completely defined by the ordered set:

$$
s_{t}=\left(B_{t}, D_{t}, y_{t}\right)
$$

When the government defaults in the international investors' debt, the economy's constraint is:

$$
c_{t}+q_{t}^{D} D_{t+1}=y_{t}\left(1-\tau^{B}\right)+D_{t}
$$

where $\tau^{\mathrm{B}}$ corresponds to the output cost of having defaulted on debt $B$. After defaulting, the sovereign is temporarily excluded from issuing international investors' debt. We assume $\theta^{B}$ to be the probability that the sovereign regains access to international investors' credit markets.

When the government defaults in the NPC investor debt, the economy's constraint is:

$$
c_{t}+q_{t}^{B} B_{t+1}=y_{t}\left(1-\tau^{D}\right)+B_{t},
$$

where $\tau^{\mathrm{D}}$ corresponds to the output cost of having defaulted on debt $D$. We assume $\theta^{D}$ to be the probability that the sovereign regains access to the NPC credit market. When the government defaults on both the international and NPC investors' debts, the economy's constraint is:

$$
c_{t}=y_{t}\left(1-\tau^{B}\right)\left(1-\tau^{D}\right)
$$

The same parameters $\theta^{B}$ and $\theta^{D}$ govern the probabilities of regaining access to the international investors and NPC credit. 
International investors are risk-neutral and have an opportunity cost of funds given by $\rho^{B}$, which denotes the risk-free rate. Investors choose the debt price $q^{B}$, which depends on the perceived likelihood of default. For these investors to be indifferent between the riskless asset and lending to the sovereign, it must be the case that:

$$
q^{B}\left(y_{t}, B_{t}, B_{t+1}\right)=\frac{1-\delta^{B}\left(y_{t}, B_{t}, B_{t+1}\right)}{\left(1+\rho^{B}\right)}
$$

where $\delta^{B}$ is the default probability on $B$ debt endogenously determined and depends on the sovereign's incentives to repay the debt.

Similarly, we assume the NPC investor is risk-neutral and has an opportunity cost given by $\rho^{D}$. The NPC investor chooses the debt price $q^{D}$, which satisfies:

$$
q^{D}\left(y_{t}, B_{t}, B_{t+1}, D_{t}, D_{t+1}\right)=\frac{1-\delta^{D}\left(y_{t}, B_{t}, B_{t+1}, D_{t}, D_{t+1}\right)}{\left(1+\rho^{D}\right)}
$$

where $\delta^{D}$ is the endogenously determined probability of default on debt $D$. Note that while $q^{D}$ depends on both types of debt, $q^{B}$ is a function only of the debt $B$ as we assume that international investors not to have information about $D$.

The timing of the decisions is as follows. In the beginning of each period, the government starts with debt levels $B_{t}$ and $D_{t}$ and observe income $y_{t}$. It faces the price schedules $q^{B}\left(y_{t}, B_{t+1}, B_{t+1}\right)$ and $q^{D}\left(y_{t}, B_{t}, B_{t+1}, D_{t}, D_{t+1}\right)$. Taking these schedules as given, the government chooses: (i) whether to repay its debt obligations to international investors; (ii) whether to repay its debt obligations to the NPC investor; (iii) if it decided not to default on the international investors, the next level of debt $B_{t+1}$; or (iv) if it decided not to default on the NPC investor, the next level of debt $D_{t+1}$. With this timing of events, there is no possibility of default at settlement and no rollover crisis (or "sunspot equilibrium"), as in Aguiar et al. (2016).

The model described is a stochastic dynamic game with incomplete information. We focus on the Perfect Bayesian Equilibrium, whereby the government does not have commitments and players act sequentially and rationally. This equilibrium concept is similar 
to the traditional (Markov Perfect) equilibrium used in sovereign default models, adapted to accommodate the fact that international investors have incomplete information about the sovereign debt to the NPC investor.

A Perfect Bayesian Equilibrium has two components: strategies and systems of beliefs. The strategy determines how players act in their information set. Players' belief determines what node in that information set they believe they are playing. The system of beliefs is a probability distribution over the nodes in the information set. In the present case, international investors need to have a belief about the level of the NPC debt; that is, a probability distribution of $D_{t}$. Strategies and beliefs satisfy the following conditions: (i) sequential rationality; that is, each strategy should be optimal in expectation, given the beliefs, and (ii) consistency; that is, each belief should be updated according to the strategies and Bayes' rule in every path of positive probability.

To describe the equilibrium, notice first that the international investors and the NPC investor are passive, and their actions can be completely described by the expressions for $q^{D}$ and $q^{B}$. To write the sovereign problem recursively, let $v^{O, B D}\left(y_{t}, B_{t}, D_{t}\right)$ denote the value function for the government that has the option to default in both types of debt and that starts the current period with output level $y_{t}$ debt levels $B_{t}$ and $D_{t}$. Given the option to default, $v^{O, B D}$ satisfies:

$$
v^{O, B D}\left(y_{t}, B_{t}, D_{t}\right)=\operatorname{Max}\left\{v^{B D}\left(y_{t}, B_{t}, D_{t}\right), v^{B}\left(y_{t}, B_{t}\right), v^{D}\left(y_{t}, D_{t}\right), v^{N O}\left(y_{t}\right)\right\}
$$

where $v^{B D}$ is the value associated with not defaulting on any type of debt, $v^{B}$ is the value associated with defaulting $D$ type of debt, $v^{D}$ is the value associated with defaulting on $B$ type of debt, and $v^{N O}$ is the value associated with defaulting on both types of debt.

Analogously, we can write the value functions in the beginning of the period when the government does not have good credit with either type of investor. Let $v^{O, B}\left(y_{t}, B_{t}\right)$ denote the 
value function in which the government can choose only whether it defaults on international investors' debt (it had lost credit access to the NPC investor), and $v^{O, D}\left(y_{t}, D_{t}\right)$ denote the value function when the government can choose only whether it defaults on the NPC investor's debt (it lost credit access to the international investors). Then

$$
\begin{aligned}
& v^{O, B}\left(y_{t}, B_{t}\right)=\operatorname{Max}\left\{v^{B}\left(y_{t}, B_{t}\right), v^{N O}\left(y_{t}\right)\right\}, \\
& v^{O, D}\left(y_{t}, D_{t}\right)=\operatorname{Max}\left\{v^{D}\left(y_{t}, D_{t}\right), v^{N O}\left(y_{t}\right)\right\} .
\end{aligned}
$$

The value functions after the government chose whether or not to default are:

$$
\begin{gathered}
v^{B D}\left(y_{t}, B_{t}, D_{t}\right)=\operatorname{Max}\left\{u\left(c_{t}\right)+\beta E v^{O, B D}\left(y_{t+1}, B_{t+1}, D_{t+1}\right)\right\}, \\
v^{B}\left(y_{t}, B_{t}\right)=\operatorname{Max}\left\{u\left(c_{t}\right)+\beta E\left[\theta^{D} v^{O, B D}\left(y_{t+1}, B_{t+1}, 0\right)+\left(1-\theta^{D}\right) v^{O, B}\left(y_{t+1}, B_{t+1}\right)\right]\right\}, \\
v^{D}\left(y_{t}, D_{t}\right)=\operatorname{Max}\left\{u\left(c_{t}\right)+\beta E\left[\theta^{B} v^{O, B D}\left(y_{t+1}, 0, D_{t+1}\right)+\left(1-\theta^{B}\right) v^{O, D}\left(y_{t+1}, D_{t+1}\right)\right]\right\}, \\
v^{N O}\left(y_{t}\right)=u\left(c_{t}\right)+\beta E\left[\theta^{B}\left(1-\theta^{D}\right) v^{O, B}\left(y_{t+1}, 0\right)+\theta^{D}\left(1-\theta^{B}\right) v^{O, D}\left(y_{t+1}, 0\right)+\right. \\
\left.\theta^{B} \theta^{D} v^{O, B D}\left(y_{t+1}, 0,0\right)+\left(1-\theta^{B}\right)\left(1-\theta^{D}\right) v^{N O}\left(y_{t+1}\right)\right],
\end{gathered}
$$

with the correspondent budget constraints, and $E$ denoting the expected value with respect to $y_{t+1}$ conditional on $y_{t}$, which is determined by the transition function $f\left(y_{t+1}, y_{t}\right)$. Note that the maximizations are over choices of $B_{t+1}$ and $D_{t+1}$ or both, depending on the case, and thus define the debt-holding policies. The default policies can be characterized by the default sets. When the government can choose only whether it defaults on international investors' debt (it has lost credit access to the NPC investor), the default set is given by:

$$
\pi^{B, B}\left(B_{t}\right)=\left\{y_{t} \in Y: v^{N O}\left(y_{t}\right)>v^{B}\left(y_{t}, B_{t}\right)\right\}
$$

Similarly, when the government can choose only whether to default on the NPC investor, the default set is:

$$
\pi^{D, D}\left(D_{t,}\right)=\left\{y_{t} \in Y: v^{N O}\left(y_{t}\right)>v^{D}\left(y_{t}, D_{t,}\right)\right\}
$$

When the government can default on both debt types, there are three default sets, which define the default in debt $B$ debt, in debt $D$, and in both types of debt:

$$
\pi^{B, B D}\left(B_{t}, D_{t}\right)=\left\{y_{t} \in Y: v^{B}>v^{B D} \text { and } v^{B} \geq v^{D} \text { and } v^{B} \geq v^{N O}\right\}
$$




$$
\begin{gathered}
\pi^{D, B D}\left(B_{t}, D_{t}\right)=\left\{y_{t} \in Y: v^{D}>v^{B D} \text { and } v^{D}>v^{B} \text { and } v^{D} \geq v^{N O}\right\} \\
\pi^{B D, B D}\left(B_{t}, D_{t}\right)=\left\{y_{t} \in Y: v^{N O}>v^{B D} \text { and } v^{N O}>v^{B} \text { and } v^{N O}>v^{D}\right\} .
\end{gathered}
$$

The recursive equilibrium is defined by the set of policy functions for government debt holdings and default choices, the price functions for international investors and the NPC investor debt, and the belief system $\varphi\left(D_{t} / y_{t}, B_{t}\right)$ such that: (i) taking the price functions as given, the government policy functions satisfy the government optimization problem, (ii) prices of debt are consistent with the government's decisions given the belief system, and (iii) the belief system is consistent with the government policies and debt prices.

The consistency of prices implies that the default probabilities and the default sets are related as follows. When a government can default only on debt to international investors (it had lost credit access to the NPC investor),

$$
\delta^{B}\left(y_{t}, B_{t}, B_{t+1}\right)=\int_{\pi^{B, B}} f\left(y_{t+1}, y_{t}\right) d y_{t+1}
$$

When a government can default only on debt to the NPC investor,

$$
\delta^{D}\left(y_{t}, D_{t}, D_{t+1}\right)=\int_{\pi^{D, D}} f\left(y_{t+1}, y_{t}\right) d y_{t+1}
$$

while when a government can default on both types of debt,

$$
\begin{gathered}
\delta^{B}\left(y_{t}, B_{t}, B_{t+1}\right)=\iint_{\pi^{B, B D} U \pi^{B D, B D}} \varphi\left(D_{t+1} / y_{t+1}, B_{t+1}\right) f\left(y_{t+1}, y_{t}\right) d y_{t+1} d D_{t+1} \\
\delta^{D}\left(y_{t}, B_{t}, B_{t+1}, D_{t}, D_{t+1}\right)=\int_{\pi^{D, B D} U \pi^{B D, B D}} f\left(y_{t+1}, y_{t}\right) d y_{t+1} .
\end{gathered}
$$

To have a belief system $\varphi\left(D_{t} / y_{t}, B_{t}\right)$ that is consistent with all policies and prices, we make it consistent with the invariant distribution of the states $\left(y_{t}, B_{t}, D_{t}\right)$. That is, given a $\varphi\left(D_{t} / y_{t}\right.$, $B_{t}$ ), we solve for all policies and prices. We then obtain the invariant distribution for the states $\left(y_{t}, B_{t}, D_{t}\right)$. We also make sure that this invariant distribution implies the same conditional probability $\varphi\left(D_{t} / y_{t}, B_{t}\right)$ that was assumed. 


\section{Calibration}

We calibrate our model to Angola, one of the largest countries in Africa, with a GDP of US\$125 billion. Since NPC lending is a recent phenomenon, we first calibrate the model without $D$ type debt, making the parameters consistent with the historical means of observable variables. We then consider the parameters associated with the NPC investor, for which we conduct many robustness tests.

We assume each period corresponds to one year. We set the intertemporal substitution parameter at $\sigma=2$ and international interest rate at $\rho^{B}=0.04$, as is typical in real business-cycle research. Setting the probability of redemption at $\theta=0.5$ implies an average remainder in autarky for two years, in line with estimates (see Aguiar and Amador (2014) and references therein).

We set $y_{t}=\exp \left(z^{T}\right)$ and assume that $z^{T}$ can take a finite number of values and that it evolves over time according to a Markov transition matrix with elements $\pi^{T}\left(z^{T}{ }_{i}, z^{T}\right)$; that is, the probability that $z^{T+1}=z^{T}$, given that $z^{T}{ }_{t}=z^{T}$, and the matrix $\pi$ element of row $i$ and column $j$. We calibrate the technology state $z^{T}$ by considering the logarithm of the Angolan GDP to follow an $\operatorname{AR}(1)$ process; that is, $z_{t+1}=\alpha z_{t}+\varepsilon_{t+1}$ where $\varepsilon \approx \mathrm{N}\left(0, \sigma^{2}\right)$. Using data from 1990 to 2017, we find that $\alpha=0.75$ and $\sigma=0.074$.

The parameters output $\operatorname{costs} \tau^{B}$ and intertemporal factor $\beta$ jointly determine the average debt level and average interest spread (which is directly linked to the probability of default). We calibrate output costs to be $\tau^{B}=0.10$, in line with the empirical evidence (Furceri and Zdzienicka, 2012) and set the intertemporal factor at the relatively low value of $\beta=0.50$, which is common practice in debt models. By doing so, as seen in the next section, we find that the average debt level is equal to $44.5 \%$ of GDP. This matches Angola's debt level over the period 2002-2016 (the available time horizon; World Bank data). Information on the Angolan interest 
spread is scarce. The EMBI+, which is available from November 2012, has an average of $540 \mathrm{bps}$, but refers to bonds with a duration of over five years. The CDS spread, with the adequate duration of one year, is available from May 2017 and has averaged 250bps. Our calibration implies an average spread of $350 \mathrm{bps}$, which is within the interval of the available data.

We now consider the full model in which the sovereign can also borrow from the NPC investor. In our benchmark calibration, we set the NPC interest rate opportunity cost at $\rho^{D}=$ 0.04 and the probability of redemption of $D$ type debt equal to $\theta^{D}=0.5$. We thus keep symmetry with the international investors and can more accurately evaluate the effect of the incomplete information assumption. We then measure how the results change with these parameters in the robustness section.

To calibrate the output cost of defaulting on the NPC debt, we resort to Angola's international trade (exports plus imports) information. In 2016, Angola's trade volume with China was $52 \%$ of its total trade. Accordingly, we calibrate $\tau^{D}=0.052$ and keep $\tau^{B}=0.10$. Given our lack of understanding about the nature of output costs, it is not clear that $\tau^{B}$ remained the same after China became a relevant player in the global economy. It could be that China played a role of substitute rather than complement to the other countries, and that $\tau^{B}$ should be reduced. We also evaluate the implications of having different values for $\tau^{B}$ and $\tau^{D}$ in the robustness section.

Table 1 reports the parameter calibration for our benchmark economy.

\section{Simulation results}

We solve three versions of our model, representing the past, the present, and perhaps the future environments: (1) the sovereign has access only to the international investors' market (no NPC investor), that is, the environment before the Belt and Road initiative, (2) the current 
situation, with both types of investors and incomplete information about the NPC debt, and (3) an environment with complete information, in which the NPC debt is disclosed. Table 2 reports various results for the (invariant distribution) equilibria of these three economies.

Version 1 (shown in in the top lines of the table) is mainly used for calibration. Since the NPC investor is not present, in this economy there are only two possible market-access conditions: either the sovereign has access to the international investor market or it does not have access to any market. As the table shows, the probabilities of these two conditions occurring are $96.7 \%$ and $3.2 \%$, respectively. Conditional on having market access, a sovereign's average debt is $42.5 \%$, which is consistent with Angola's average debt during the last 16 years. We normalize the sovereign welfare level, measured by consumption, to zero.

Version 2 of the model represents the current situation and warrants more discussion. There are four market access conditions: (i) the sovereign has access to both types of investors, (ii) the sovereign has access only to international investors (it has defaulted on the NPC debt), (iii) the sovereign has access only to the NPC market (it has defaulted on the international investors), and (iv) the sovereign does not have access to any credit market (it has defaulted on both types of debts).

When the sovereign has access to only one type of investor, the solution of the model is similar to that of an economy with only international investors (version 1). The sovereign can take two actions: default or accept the next period level of debt. As shown in other papers (e.g. Arellano, 2008), default is more likely at higher levels of original debt and in lowendowment states. Next-period debt is an increasing function of this period debt, and also an increasing function of the endowment; that is, even though the sovereign wants to borrow more in tough periods, it is too expensive to do so (see Alfaro and Kanczuk, 2004).

When the sovereign has access to both credit markets, it can decide on four actions: whether to default on the international investors, whether to default on the NPC investor, and, 
conditional on not defaulting, whether to accept debt for the next period from international investors and NPCs. We find that these four policy functions have exactly the same properties as before: (i) default (on a certain type of debt) is more likely with higher debt levels, (ii) default is more likely with lower output endowment; (iii) next-period debt (of a certain type) is higher with higher this period debt (of the same type), (iv) debt is higher for lower endowments.

As expected, what drives the novel results of our model is that it depicts how defaulting on one type of debt relates to the level of the other type of debt. Figure 1 reports the decision to default on international investors' debt as a function of the amount of both types of debt for a given endowment shock equal to zero. (The decision to default on NPC, not reported, has the same characteristics). It shows that defaulting on international investors is more likely with higher NPC debt. The reason is that, after having defaulted, the sovereign can still use the NPC debt to smooth consumption and can do so more powerfully when it has higher debt (especially because the sovereign can default on NPC debt as well). Because the cost of defaulting on international investors is ameliorated by accepting higher NPC debt, it happens more often.

This is an important intuition, which determines much of the debt sustainability results. There is some complementarity between the two types of debt. As a consequence, one should expect that the advent of NPC investors would reduce international investors' debt sustainability. The question is whether this is quantitatively relevant or not.

Another important issue is how incomplete information affects actions. The easiest approach is to observe how private investors assess the probability that the sovereign will default on the debt. Figure 2 shows that this probability is conditional on the endowment (technology shock equal to zero) and conditional on the international investors' debt (equal to $3 \%$ of GDP). If there were complete information, the probability of default would be either one or zero, depending on the value for NPC debt. This is a horizontal slice of Figure 1 taken at the point $B=3 \%$. 
In contrast, when there is incomplete information, the probability of default is constant, equal to about $78 \%$, regardless of the NPC debt level; that is, it is equal to the complete information default decision weighted by the invariant distribution probability for the NPC debt. Conditional on zero technology shock and international investors' debt $B=3 \%$, the NPC debt $D$ is above its sustainable level $78 \%$ of the time.

The lesson from Figure 2 is simply that incomplete information is potentially very costly. Since international investors cannot observe NPC debt, they will often assign a probability of default on their lending that is very different from the actual probability. Consequently, the sovereign will end up having lower benefits from access to the international credit markets. We next quantify these effects by looking at the invariant distributions.

Going back to Table 2, the second and third groups of rows report the invariant distribution information for versions 2 and 3 of the model. It is easier to first analyze version 3 of the model, as this is more similar to version 1.

Comparing version 3 with version 1, one can notice that the inclusion of NPC markets reduces the sustainability of the international investor's debt. When only international markets are lending, the average debt is $38.5 \%$ of GDP, which is close to the average debt in version 1 . But this state now happens less often. Its frequency dropped from $96.7 \%$ to $62.2 \%$, as the sovereign now has more options. The state with both credit markets operative occurs $32 \%$ of the time, but debt levels are small. The state in which both credit markets are closed occurs $2.8 \%$ of the time, less often than in the version 1 .

In comparing version 3 with version 1, one notices that the NPC is more like a substitute than a complement to the international investor. But it is not a perfect substitute, as the sovereign uses this additional option to achieve more consumption smoothing.

Another observation from version 3 is the asymmetry between the NPC investor and the international investors. As this version assumes full information, the only reason for 
asymmetry between the two types of lending is the different output costs from defaulting. Since the output costs from defaulting on NPC debt are smaller, the sustainability of this type of debt is much smaller than the international investor's debt.

Version 2 introduces another asymmetry between the two types of debt by assuming that NPC debt is not observable to international investors. As international investors reassess the probability of default, they cannot price debt with the same precision, and the sovereign benefits from this market are reduced. Consequently, as in models of credit rationing, the equilibrium displays smaller amounts of international investors' debt. Note in Table 2 that for the state in which only the international investors' market is open, the average debt is $24.7 \%$, but this state happens only $27.5 \%$ of the time.

Another consequence of the incomplete information is that of increased NPC debt sustainability. This is expected if one sees the two types of debt as (imperfect) complements. With the increase in international investor debt price, the sovereign opts to borrow more from the NPC investor. Note that average NPC debt increases to $9.6 \%$ and $6.7 \%$ of GDP, respectively, in the states with both debts and with only NPC debt. These numbers are much higher than in their correspondents in version 3 , but they are smaller than the international investors' numbers (version 2). Thus, even though incomplete information reduces the difference in debt sustainability between the two types of debt, its effect is not strong enough to make NPC debt more sustainable than international investors' debt. In other words, incomplete information is not as strong a device to increase debt sustainability as default output costs.

A final observation of Table 2 refers to welfare. As expected, sovereign welfare increases from version 1 to version 2, and increases from version 2 to version 3 . This calls for reflection and speculations about the present and future of undisclosed sovereign debt. Our 
results indicate that the welfare gains from tapping into the NPC credit market are substantial. ${ }^{3}$ Another present-day issue is the lack of transparency of NPC lending. Multilateral banks have expressed concern about this lack of transparency, listing it as a top priority. The IMF, in particular, is urging creditors to disclose more information. Our model provides a framework for thinking about this issue, indicating that NPC debt works as a (imperfect) substitute to the traditional international investor (Paris Club) debt. Moreover, it quantifies the reduction in debt sustainability.

\section{Robustness}

\subsection{Sensitivity Analysis}

Here we look at how different parameter calibrations affect our results; in particular, the sustainability of international investors' debt. First we solve our model for different $\beta$ values (sovereigns' impatience). In models of sovereign debt, as that used in this paper, this is the most critical parameter in determining debt sustainability. By changing $\beta$, we can evaluate what the model would predict if it was calibrated to economies that initially supported more (or less) debt. We can think about these other economies as resembling other middle- and lowincome countries that have recently tapped into the NPC market.

Figure 3 shows how different values of $\beta$ affect private investors' debt with and without the presence of the NPC investor. (These correspond to the results of version 1 and version 2 of the model). As expected, debt sustainability decreases with beta and decreases if the NPC investor is present. An interesting quantitative result is that the effect of the NPC presence on sustainability is much more severe when beta is low. Regardless of the initial level of

\footnotetext{
${ }^{3}$ Our model is silent about political issues, such as the interests of the governing elites not being aligned with those of the population; see Dreher at al. (2019).
} 
sustainability, the presence of the NPC investor will reduce debt sustainability to a fairly low value.

Next, we see how our results change if the NPC has a smaller opportunity cost of lending. Figure 4 shows how international investors' and NPC debt changes with different values of $\rho^{D}$ (always in the state with both credit markets open in version 2 ). Note that reductions in $\rho^{D}$ may result in large changes in debt sustainability. This could mean that NPC debt sustainability is higher than in our benchmark calibration. But that would mean that international investors' debt sustainability is substantially lower.

We perform sensitivity analysis to assess changes in output costs of default ( $\tau^{B}$ and $\tau^{D}$ ) and the probability of redemption $\left(\theta^{B}\right.$ and $\left.\theta^{D}\right)$. These are equivalent cases since both parameters affect the sovereign costs of defaulting. Results are as expected. Higher costs of default imply more debt sustainability. Increases in NPC debt imply a reduction in international investors' debt.

\subsection{Collateralized Debt}

A fairly common observation of China's lending is that it is collateralized, or not subject to "traditional" default. Thus, even if the sovereign wants to interrupt service payments, contracts allow for some form of recovery and service. If the collateral is an asset, it could be seized and its dividends collected in place of debt services. (The seizure of Sri Lanka's Hanbantota port in 2017 is commonly cited as evidence.) On the other hand, there is also evidence that deferments, refinancing, and new terms are much more common than asset seizures. ${ }^{4}$ Our model, consistent with sovereign debt literature, assumes that the sovereign can default, and that willingness to pay rather than ability to pay determines debt sustainability.

\footnotetext{
4 “An examination of 38 Chinese debt renegotiations with 24 countries..., concluded that China's leverage remains limited, with many of the renegotiations resolved in favour of the borrower" (Financial Times, 29 April, 2019, "China Renegotiated \$50bn to developing countries").
} 
The rationale is that military actions motivated by default have now become rare. In contrast, it is much more common that sovereigns "nationalize," or seize foreign assets in their territories.

Notwithstanding the above comments, it is interesting to evaluate how international investors' debt sustainability would be affected if NPC debt were fully collateralized and the sovereign could not default on it. Consider the following simplification. Suppose the sovereign borrowed $D$ from the NPC investor and has already consumed this amount in previous periods. That is, the sovereign has reached a "steady state" in which it has to pay the debt services, $\rho D$, to the NPC investor, and cannot default or avoid this payment.

In this case, since the sovereign has no choices related to the NPC debt, the environment is exactly like one in which there is only one type of debt, but with an additional constant in the budget constraint. Rather than receiving an endowment output of $y_{t}$, the sovereign receives $y_{\leftarrow}-\rho D$, where $\rho D$ is constant. Therefore, the solution will be as in the case with only international investors, but with a different calibration, with $y_{t}{ }^{\prime}=y_{\leftarrow}-\rho D$. Put differently, since the endowment would be smaller, the economy would be like one with a smaller GDP, and therefore a higher debt over GDP.

For an extreme example, consider that Angola's NPC debt is 50\% of GDP. Since $\rho=4 \%$, debt service is $\rho D=2 \%$ of GDP. Therefore, the effect of the NPC debt over international investor debt sustainability will be approximately $2 \%$. Rather than the original $42.5 \%$, the new sustainable debt level will be approximately $41.7 \%$ of GDP.

Why is the effect of a collateralized NPC debt much smaller than if it were not collateralized? The reason is that debt sustainability depends on the marginal benefits and costs of defaulting. The benefits of defaulting on the international investor's debt is not to pay debt services, which is (about) the same whether the sovereign has other types of debt. In contrast, the costs of defaulting on the international investors depends a lot on what the sovereign has 
left as alternative devices to smooth consumption once it is excluded from the international investor's credit market. When NPC debt is collateralized, the sovereign does not apply any device to smooth consumption. When NPC is not collateralized, the sovereign can still default on this debt to smooth consumption. The costs of defaulting on the international investor debt are much smaller if NPC debt is not collateralized. Hence, it is in this case that debt sustainability is greatly affected.

\section{Conclusion}

By uniquely presenting a hypothetical scenario in which non-Paris Club lending and borrowing is fully disclosed, we illustrate that transparency has potential effects of decreased debt sustainability for investors such as China and significant welfare gains for recipient countries. We find that these implied effects are particularly strong if the debt is large. We caveat the results of this model by showing how the relationships between borrowers, traditional investors and NPC investors affect these results. These results vary even further when the opportunity cost of lending changes, with sovereigns choosing to default on debts to one type of investor in order to smooth consumption and alleviate debts to the other. These varying factors affect the level of debt sustainability significantly, and must be recognized as forming a complex, interactive system.

\section{References}

Aguiar, Mark and Manuel Amador (2014). "Sovereign Debt." In Handbook of International Economics, vol. 4, eds. Gita Gopinath, Elhanan Helpman and Kenneth Rogoff, Elsevier. 
Aguiar, Mark, Satyajit Chatterjee, Harald Cole, and Zachary Stangebye (2016). “Quantitative Models of Sovereign Debt Crises," Handbook of Macroeconomics, vol. 4, eds. Harald Uhlig and John Taylor.

Agarwal, Isha, Grace Weishi Gu, and Eswar Prasad (2019). "China's Impact on Global Financial Markets,” Working Paper.

Alfaro, Laura and Fabio Kanczuk (2005). "Sovereign Debt as a Contingent Claim: A Quantitative Approach,”Journal of International Economics 65(2): 297-314.

Alfaro, Laura and Fabio Kanczuk (2009). "Optimal Reserve Management and Sovereign Debt," Journal of International Economics 77(1): 23-36.

Alfaro, Laura, Sebnem Kalemli-Ozcan, and Vadym Volosovych (2014). "Sovereigns, Upstream Capital Flows and Global Imbalances." Journal of the European Economic Association 12 (5): 1240-1284

Arellano, Cristina (2008). "Default Risk and Income Fluctuations in Emerging Economies," American Economic Review 98(3): 690-712.

Bulow, Jeremy and Kenneth Rogoff (1989). "Sovereign Debt: Is to Forgive to Forget?" American Economic Review 79: 43-50.

Cole, Harold L. and Patrick J. Kehoe (1995). "The Role of Institutions in Reputation Models of Sovereign Debt," Journal of Monetary Economics 35: 45-64.

Dreher, Axel, Andreas Fuchs, Roland Hodler, Bradley C. Parks, Paul A. Raschky, and Michael J. Tierney (2019). “African Leaders and the Geography of China’s Foreign Assistance," Journal of Development Economics 140: 44-71.

Eaton, Jonathan and Mark Gersovitz (1981). "Debt with Potential Repudiation: Theoretical and Empirical Analysis," The Review of Economic Studies 48: 289-309.

Farhi, Emmanuel and Matteo Maggiori (2019). "China versus the United States: IMS meets IPS.”American Economic Review 109 (May): 476-481. 
Foresight Africa (2018). “Top Priorities for the Continent in 2018," Africa Growth Initiative at Brookings.

Furceri, Davide and Aleksandra Zdzienicka (2012), "How Costly Are Debt Crises?, Journal of International Money and Finance 31(4): 726-742.

Horn, Sebastian, Carmen M. Reinhart, and Christoph Trebesch (2019). "China's Overseas Lending,” NBER Working Paper No. 26050.

Ilzetzki, Ethan, Carmen M. Reinhart, and Kenneth Rogoff (2019). "Exchange Arrangements Entering the 21st Century: Which Anchor Will Hold?" Quarterly Journal of Economics 134(2): 599-646.

Mendoza, Enrique and Vivian Yue (2012). "A General Equilibrium Model Of Sovereign Default and Business Cycles," Quarterly Journal of Economics 127(2): 889-946.

World Bank, 2018. International Debt Statistics, Washington DC. 
Table 1: Calibration

\begin{tabular}{lcc}
\hline Parameter & Calibration & Data matched \\
\hline Risk aversion & $\sigma=2$ & Real Business Cycle \\
International riskless interest rate & $\rho^{B}=0.04$ & Real Business Cycle \\
Technology shock autocorrelation & $\alpha=0.75$ & GDP AR(1) process \\
Technology shock standard deviation & $\sigma=0.074$ & GDP AR(1) process \\
Probability of international redemption & $\theta^{B}=0.50$ & Duration of each default \\
International Output costs & $\tau^{\mathrm{B}}=0.10$ & Interest Rate Spread \\
Discount factor & $\beta=0.50$ & Debt over GDP \\
\hline NPC investor interest cost & $\rho^{D}=0.04$ & Same as International \\
Probability of NPC redemption & $\theta^{D}=0.50$ & Duration of each default \\
NPC debt output cost & $\tau^{\mathrm{D}}=0.052$ & China-Angola trade \\
\hline
\end{tabular}

Table 2: Invariant Distribution Properties

\begin{tabular}{|c|c|c|c|c|c|}
\hline Economy & $\begin{array}{l}\text { State } \\
\text { (Investor Types) }\end{array}$ & $\begin{array}{c}\text { Probability } \\
(\%)\end{array}$ & $\begin{array}{l}\text { Debt } \\
\text { Type }\end{array}$ & $\begin{array}{c}\text { Debt } \\
(\% \text { GDP })\end{array}$ & $\begin{array}{l}\text { Welfare } \\
(\% \text { GDP })\end{array}$ \\
\hline \multirow{5}{*}{$\begin{array}{l}\text { Version 1: } \\
\text { Without NPC } \\
\text { Investors }\end{array}$} & Both & - & B & - & \multirow{5}{*}{0} \\
\hline & & & $D$ & - & \\
\hline & International & 96.7 & B & 42.5 & \\
\hline & NPC & - & $\mathrm{D}$ & - & \\
\hline & None & 3.2 & - & - & \\
\hline \multirow{5}{*}{$\begin{array}{l}\text { Version 2: } \\
\text { With NPC Investors, } \\
\text { Incomplete } \\
\text { Information }\end{array}$} & Both & 24.7 & B & 20.3 & \multirow{5}{*}{7.2} \\
\hline & & & $\mathrm{D}$ & 9.6 & \\
\hline & International & 27.5 & B & 24.7 & \\
\hline & NPC & 11.0 & $\mathrm{D}$ & 6.7 & \\
\hline & None & 36.8 & - & - & \\
\hline \multirow{5}{*}{$\begin{array}{l}\text { Version 3: } \\
\text { With NPC Investors, } \\
\text { Complete } \\
\text { Information }\end{array}$} & $\overline{\text { Both }}$ & 32.5 & $\bar{B}$ & $\overline{16.5}$ & \multirow{5}{*}{9.0} \\
\hline & & & $\mathrm{D}$ & 1.0 & \\
\hline & International & 62.2 & $\mathrm{~B}$ & 38.5 & \\
\hline & NPC & 2.5 & $\mathrm{D}$ & 0.1 & \\
\hline & None & 2.8 & - & - & \\
\hline
\end{tabular}


Figure 1: Default Set for Neutral Technology Shock

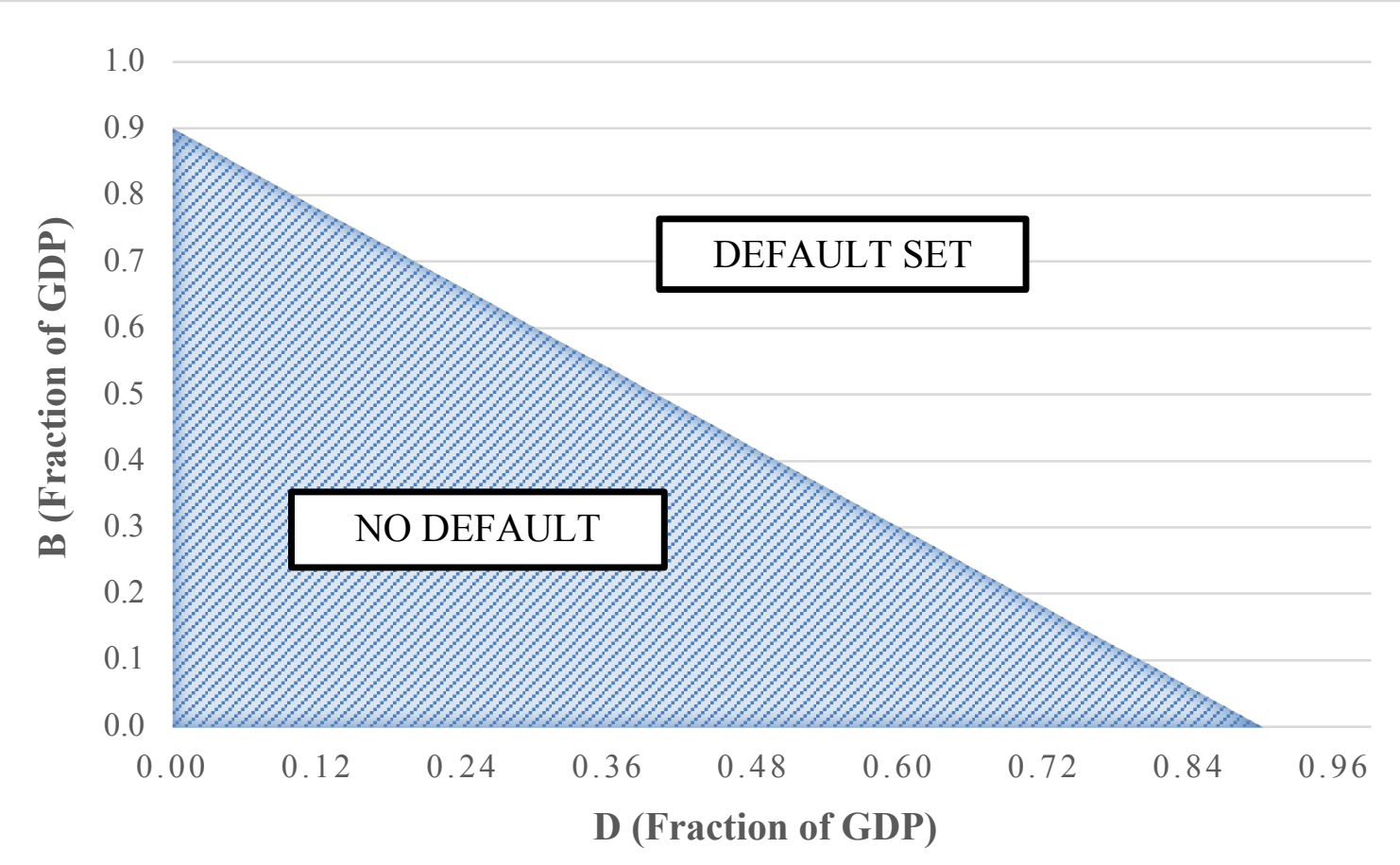

Figure 2: International Investors' Assessment of Probability of Default

1.2

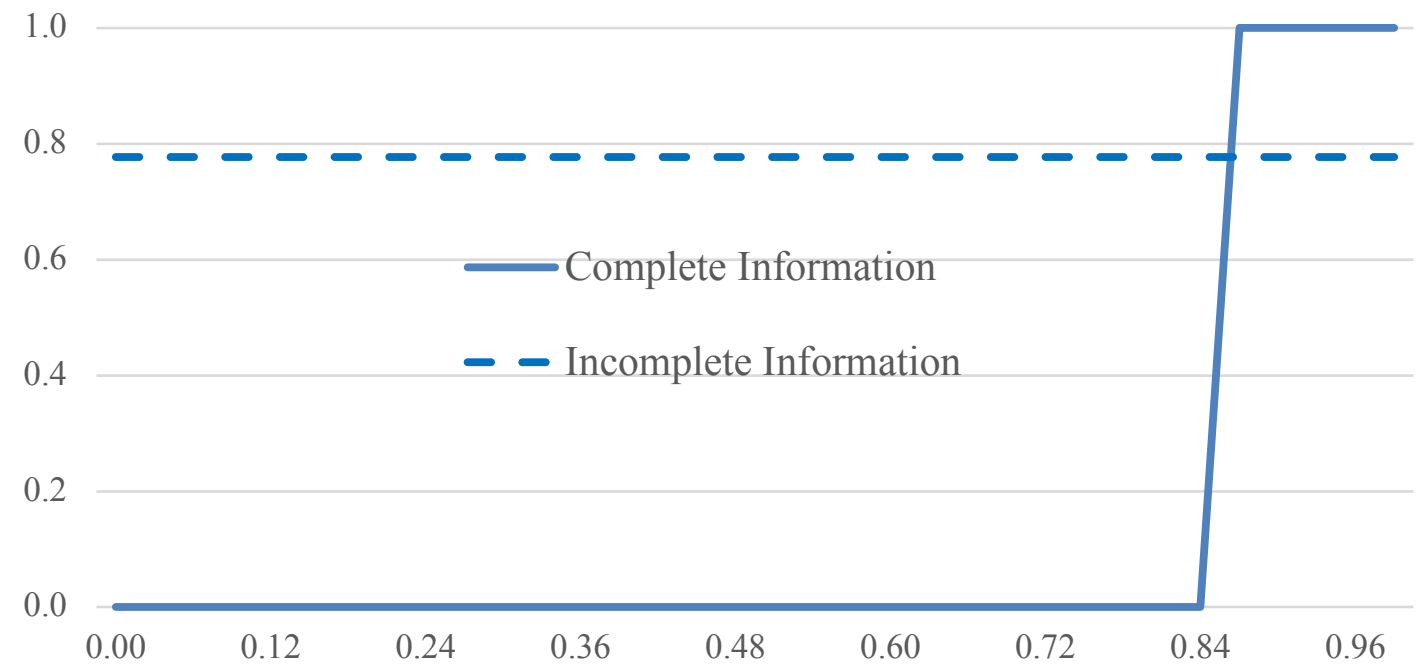

$-0.2$

D (Fraction of GDP) 
Figure 3: Undisclosed Debt Sustainability

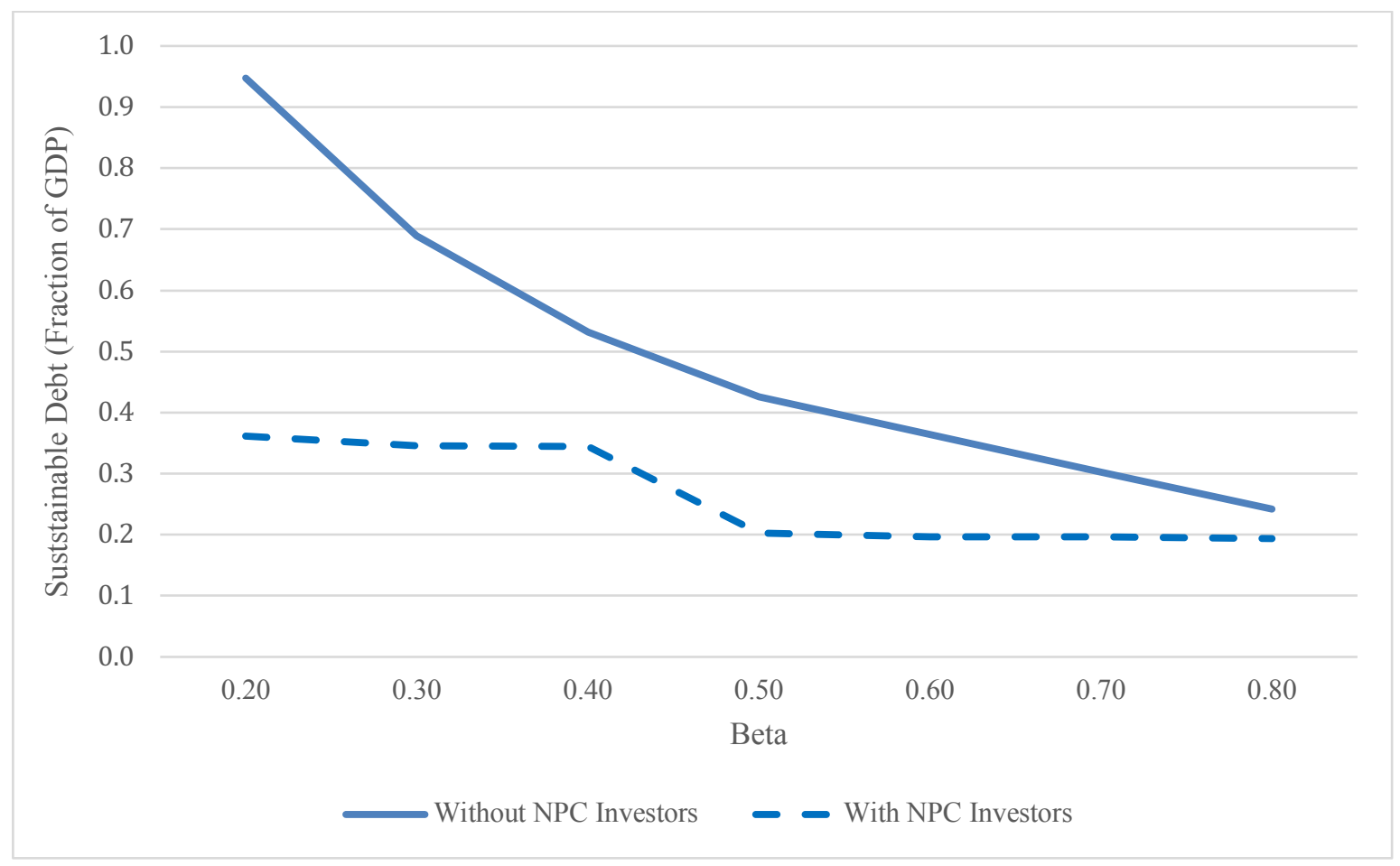

Figure 4: Sensibility to NPC Opportunity Interest Rate

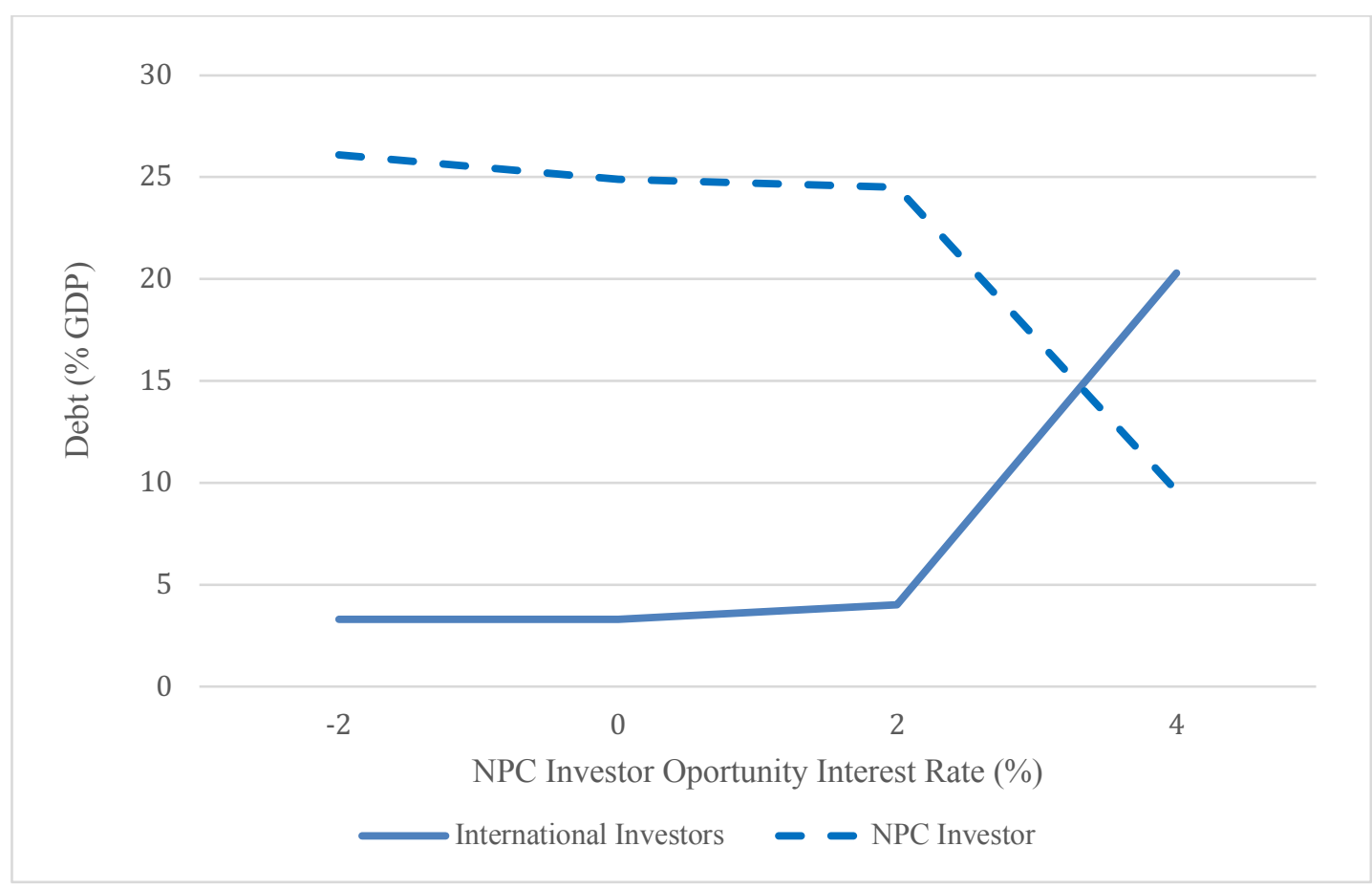

